\title{
Eger környéki borok antocianin összetételének tömegspektrometriás vizsgálata
}

\section{Román Gergely, Kursinszki László*}

Semmelweis Egyetem, Farmakognóziai Intézet, 1085 Budapest, Üllői út 26.

*e-mail: kursinszki.laszlo@pharma.semmelweis-univ.hu

Az antocianinok a fenoloidok hatóanyag osztályába tartozó speciális anyagcseretermékek, melyek felelősek a kék szőlők és a vörös borok színéért. Jelentős szerepet játszanak a borok érési és öregedési folyamatai során, továbbá fajtaeredetük meghatározásában. Mérsékelt borfogyasztás esetén jelentős egészségvédő hatásuk is lehet. Jelen előadás Eger környéki borok antocián-összetételének vizsgálatával kapcsolatos eredményekről számol be.

Munkánk során egy családi pincészetből származó, különböző évjáratú Pinot Noir (2017, 2016, 2015), Merlot (2017, 2016), és Kadarka (2017, 2016) borok antocianin spektrumát vizsgáltuk. A minták analíziséhez egy nagyhatékonyságú folyadékkromatográfiás készülékkel kapcsolt, elektroporlasztásos ionforrással szerelt, hármas kvadrupól tandem tömegspektrométert használtunk, pozitív ionizációs üzemmódban. A HPLC elválasztásokat Zorbax SB-C18 Solvent Saver plus $(3,5 \mu \mathrm{m})$ fordított fázisú oszlopon (150x3,0 mm i.d.) végeztük, lineáris gradiens elúcióval, 2\%-os (v/v\%) vizes hangyasav és $2 \%(\mathrm{v} / \mathrm{v} \%)$ hangyasavat tartalmazó acetonitril oldószerek felhasználásával. Az antocianinok azonosítása során a kromatográfiás csúcsok retenciós idejét és tandem MS spektrumát hasonlítottuk össze autentikus standard megfelelő értékeivel, illetve az irodalomban közölt adatokkal. Az antocianinok mennyiségi LC-MS meghatározását peonidin-3-O- $\beta$-glükopiranozid autentikus standard felhasználásával, szelektált ionpásztázásos (SIM) üzemmódban végeztük.

$\mathrm{Az}$ eredményeket összegezve, a kvalitatív analízis során összesen 17 komponenst azonosítottunk, köztük antocianidin-monoglikozidokat és monoglikozid észtereket, valamint malvidinszármazék piranocianidineket. A vizsgált borfajták, és évjárataik összehasonlító elemzése során az antocianin-összetételben és -tartalomban egyaránt jelentős, a fajtaeredettel összhangban álló eltéréseket találtunk. 